Dr NIKICA BARIĆ, znanstveni savjetnik

Hrvatski institut za povijest

UDK 94(497.5)"1941/1945"

Zagreb, Opatička 10

$359(497.5) " 1941 / 1945 "$

\title{
DJELOVANJE I USTROJ MORNARICE NDH NA RIJEKAMA
}

\begin{abstract}
APSTRAKT: Zbog nepovoljnih uvjeta Rimskih ugovora od 18. svibnja 1941. Nezavisna Država Hrvatska (NDH) na svom dijelu Jadrana nije mogla držati ratnu mornaricu. Nakon njemačkog napada na Sovjetski Savez dio mornara NDH upućen je na istočno bojište, gdje se borio u sastavu njemačke Ratne mornarice. Kada je u rujnu 1943. kapitulirala Kraljevina Italija, NDH je u svoj sastav vratila većinu krajeva na Jadranu koje je izgubila Rimskim ugovorima. Time se otvorila i mogućnost intenzivnijeg razvoja njezine ratne mornarice. Iako su u tome postignuti određeni rezultati, oni su bili ograničeni nizom nepovoljnih okolnosti koji su u kasnijem razdoblju Drugoga svjetskoga rata vladali na hrvatskom dijelu Jadranu. U ovom radu prikazano je djelovanje Mornarice NDH na rijekama, gdje je ona imala sustav zapovjedništava $i$ lučkih poglavarstava, a raspolagala je i određenim brojem plovnih jedinica, od ophodnih redarstvenih čamaca do riječnih ratnih brodova, koji su ušli u sastav njezine Riječne ratne flotile.
\end{abstract}

Ključne riječi: Nezavisna Država Hrvatska, Ratna mornarica Nezavisne Države Hrvatske, Riječna ratna flotila Nezavisne države Hrvatske

\section{Uvod}

Rimskim ugovorima koje su Kraljevina Italija i NDH potpisale 18. svibnja 1941. u sastav Italije ušli su znatni dijelovi istočne jadranske obale. Tim ugovorima NDH se također odrekla držanja ratne mornaricu na dijelu Jadrana koji je, nakon razgraničenja s Italijom, ostao u njezinom sastavu. NDH je na moru mogla raspolagati isključivo jedinicama za redarstvenu i rizničku službu. Talijani su ratne brodove Kraljevine Jugoslavije preuzeli kao ratni plijen. NDH je nakon njemačkog napada na Sovjetski Savez na istočno bojište uputila dobrovoljce, hrvatske legionare, koji su se borili $u$ sastavu njemačke i talijanske vojske. Tako je ustrojen i Hrvatski pomorski 
odjel (Hrvatska pomorska legija) koji je u sastavu njemačke Ratne mornarice djelovao na Crnom i Azovskom moru. Nakon kapitulacije Kraljevine Italije u rujnu 1943., NDH je dobila mogućnost pod svoju vlast vratiti najveći dio teritorija koje su Talijani anektirali Rimskim ugovorima. To je također otvorilo mogućnost razvoja Mornarice NDH na Jadranu. No, zbog niza okolnosti, nepovoljnih za NDH, u razdoblju nakon talijanske kapitulacije njemačka Ratna mornarica je na Jadranu imala puno važniju ulogu od Mornarice NDH. Nasuprot Talijanima, Nijemci su ipak bili spremni pomoći razvoju Mornarice NDH na Jadranu. Njemačka vojska je u međuvremenu preuzela operativno zapovjedništvo nad postrojbama NDH, kao i brigu za njihov ustroj i razvoj. Tako je njemački opunomoćeni general u Hrvatskoj, Edmund Glaise von Horstenau, među ostalim svojim dužnostima imao zadatak da, putem njemačkog „Mornaričkog stožera za vezu Hrvatska“, radi i na razvoju Mornarice NDH. Krajem svibnja 1944. Hrvatska pomorska legija se s istočnog bojišta vratila u Hrvatsku. Njezini pripadnici, do tada u sastavu njemačke Ratne mornarice, vraćeni su u sastav Mornarice NDH i upućeni na Jadran. Oni su, među ostalim, trebali preuzeti plovne jedinice koje su im dodijelili Nijemci. No, do kraja 1944., zbog nepouzdanosti hrvatskog mornaričkog osoblja, od kojih je dio prebjegao partizanima, Nijemci su imali sve manje povjerenja da pripadnike Mornarice NDH koriste za službu na Jadranu. ${ }^{1}$

Tijekom 1941. u sastavu Zapovjedništva Mornarice NDH osnovano je Zapovjedništvu rijeka i riječnog prometa sa sjedištem u Sisku. Njemu su bila podređena lučka poglavarstva na Dravi, Dunavu i Savi. ${ }^{2}$ Krajem 1941. određeno je da je cjelokupno osoblje riječnog brodarstva u stegovnom smislu podređeno Ministarstvu hrvatskog domobranstva, ${ }^{3}$ što je zapravo značilo Zapovjedništvu Mornarice NDH.

Čini se da je tijekom 1942. Zapovjedništvo rijeka i riječnog prometa u Sisku ukinuto. Umjesto toga uvedena su nova obalna zapovjedništva u

* Ovaj prilog temelji se na izlaganju „Mornarica Nezavisne Države Hrvatske na rijeci Savi“, kojeg sam održao na znanstvenom skupu „Rijeka Sava u povijesti“ koji je, u organizaciji Hrvatskog instituta za povijest - Podružnica za povijest Slavonije, Srijema i Baranje, održan u Slavonskom Brodu 18. i 19. listopada 2013. Opširnija pismena verzija navedenog izlaganja trebalo bi tijekom 2014. biti objavljena u zborniku radova znanstvenog skupa, dok ovaj prilog predstavlja njegovu skraćenu verziju.

${ }^{1}$ Opširnije o Mornarici NDH na Jadranu vidjeti: Nikica Barić, Ustaše na Jadranu, Uprava Nezavisne Države Hrvatske u jadranskoj Hrvatskoj nakon kapitulacije Kraljevine Italije, Zagreb 2012, 247-270. Opširnije o Hrvatskoj pomorskoj legiji na istočnom bojištu vidjeti: Andro Vrkljan, Hrvatski Argonauti 20. stoljeća, Povijest Hrvatske pomorske legije na Crnom moru 1941.-1944., Urednik Vladimir Brnardić, Prilozi Zvonimir Freivogel, Zagreb 2011.

${ }^{2}$ Mladen Colić, Takozvana Nezavisna Država Hrvatska, 1941., Beograd 1973, 250.

${ }^{3}$ Zbornik zakona i naredaba Nezavisne Države Hrvatske, god. I., br. 11, Zagreb, 15. 12. $1941,921$. 
Brodu na Savi i Zemunu. Ta obalna zapovjedništva bila su podređena Zapovjedništvu Mornarice NDH u Zagrebu, dok su obalnim zapovjedništvima bila podređena lučka poglavarstva. Obalnom zapovjedništvu u Brodu na Savi podređena su lučka poglavarstva u Brodu na Savi, Hrvatskoj Mitrovici i Sisku. Obalnom zapovjedništvo u Zemunu podređena su lučka poglavarstva u Osijeku, Petrovaradinu, Vukovaru i Zemunu. Od plovnih jedinica na rijekama Mornarica NDH je na početku raspolagala samo s redarstvenim čamcima. Prema nekim podacima tijekom 1941. za djelovanje na rijekama na raspolaganju je bio samo redarstveni čamac „Ustaša“. Kasnije je Mornarica NDH u riječnu službu uključila još pet redarstvenih čamaca („Pakra“, „Petrinjčica“, „Plitvica“, „Pliva“ i „Prača“). ${ }^{4}$ Prema nekim izvorima, navedenih pet čamaca isporučili su Nijemci, a prethodno su ti čamci pripadali Nizozemskoj. ${ }^{5}$

Za izobrazbu mornara-novaka u Sisku je 1941. osnovana Mornarička novačka škola. U njoj je tijekom 1941. bilo oko 300 ljudi. ${ }^{6}$ Predstavnici njemačkog Mornaričkog stožera za vezu Hrvatska obišli su 18. srpnja 1944. Mornaričku novačku školu u Sisku. Zaključili su da ona odgovara zahtjevima koji se pred nju postavljaju. Škola je bila organizirana jednostavno, ali djelotvorno. Čistoća i red u njoj ocijenjeni su besprijekornim, a zapovjedno i nastavno osoblje, kao i novaci, ostavili su na njemačke predstavnike dobar dojam. I u tom razdoblju u Mornaričkoj novačkoj školi bilo je nešto više od 300 ljudi. $^{7}$

Tijekom 1941. u Zemunu je ustrojena i Mornarička bojna. Jedna njezina sat nalazila se u Osijeku, a dvije u Zemunu. Krajem studenog 1941. mornarička sat u Osijeku je raspuštena, odnosno njezino ljudstvo upućeno je u sastav Mornaričke bojne u Zemunu. ${ }^{8}$ Za razdoblje nakon 1941. nisam našao podatke o daljnjem postojanju i djelovanju ove bojne.

\section{Mornarica NDH na rijekama tijekom 1942. i početkom 1943. godine}

S pojavom i razvojem partizanskog pokreta u Bosni, Slavoniji i Srijemu rijeka Sava postaje sigurnosni problem za vlasti NDH, kao i za njemačku vojsku. Partizani su iz Slavonije i Srijema preko Save prevozili stoku i žito za prehranu svojih jedinica u Bosni. Isto tako partizani su sa obala

${ }^{4}$ Jovan Vasiljević, Mornarica Narodnooslobodilačke vojske Jugoslavije, Beograd 1972, 422.; Colić, Takozvana NDH, 250.

${ }^{5} \mathrm{http}: / /$ www.forum-marinearchiv. de/smf/index. php? topic=4547.0, pristup ostvaren 17 . kolovoza 1944.

${ }^{6}$ M. Colić, Takozvana NDH, 250.

${ }^{7}$ Zbornik dokumenata i podataka o Narodnooslobodilačkom ratu naroda Jugoslavije, tom XII, knjiga 4, Dokumenti Nemačkog Rajha 1944-1945., Beograd 1979, dok. br. 102.

${ }^{8}$ M. Colić, Takozvana NDH, 250, 458. 
Save ugrožavali promet na njoj. ${ }^{9}$ Tako je Velika župa Posavje u Brodu na Savi 7. svibnja 1942. obavijestila podređene vlasti da je poduzeto „redarstveno čišćenje“ obala rijeke Save, kako bi se suzbilo djelovanje partizana. Tu akciju trebala je provesti njemačka vojska, odnosno njezino redarstvo za osiguranje vodenih putova (Wasserschutzpolizei), kao i Mornarica NDH. U sklopu ove akcije sva plovila s desne, odnosno bosanske obale Save, trebale su biti premještena na lijevu, odnosno slavonsku obalu i prikupljena na odgovarajućem mjestu pod nadzorom mjesnih vlasti. Ovime je trebalo spriječiti partizane da iz Bosne prelaze u Slavoniju. Navedenu akciju trebale su pomoći i ustaške postrojbe, oružništvo i upravne vlasti, a po potrebi i stanovništvo. Svi oni trebali su nadzirati Savu, kako partizani ne bi prelazili na njezinu slavonsku obalu, i kako bi se spriječilo da partizani ometaju plovidbu tom rijekom. U posavskim mjestima u kojima se ne može imati povjerenje u stanovništvo sve čamce i skele bilo je potrebno prikupiti i predati na čuvanje najbližoj domobranskoj postrojbi, oružničkoj postaji ili općinskom poglavarstvu. ${ }^{10}$

Tijekom lipnja i srpnja 1942. pod njemačkim zapovjedništvom provedena je operacija uništenja partizanskih snaga na planini Kozari u sjeverozapadnoj Bosni. U toj operaciji sudjelovale su i znatne domobranske i ustaške snage, ali i Kraljevska mađarska dunavska flotila. Njezini brodovi su trebali nadzirati rijeku Savu između Bosanske Gradiške i Jasenovca, kako bi spriječili pokušaje partizana da se čamcima prebace preko Save i izbjegnu opkoljavanje i uništenje. ${ }^{11}$ Prema podacima nadležnih njemačkih zapovjedništava u razdoblju od 10. do 20. lipnja 1942. mađarski riječni ratni brodovi su tijekom blokade spomenutog dijela rijeke Save više puta uspješno djelovali. ${ }^{12} \mathrm{O}$ borbama za uništenje partizana na Kozari vođenim od 6. do 12 srpnja u dokumentima njemačke vojske navodi se i da su njemačke snage, zajedno s mađarskim riječnim ratnim brodovima, uspješno razbile „prikupljanje bandi u dolini Save“, odnosno onemogućile su pokušaje partizana da prelaskom te rijeke izbjegnu opkoljavanje. ${ }^{13}$

Tijekom druge polovice srpnja 1942. mađarski riječni ratni brodovi koji su sudjelovali u operaciji protiv partizana na Kozari napustili su rijeku

${ }^{9}$ J. Vasiljević, Mornarica NOVJ, 387, 390-391.

${ }^{10}$ Arhiv SR Hrvatske u Zagrebu, Regesta dokumenata za historiju NOB-e, Svezak I, Zagreb 1964, 1942. godina, regesta br. 184.

${ }^{11}$ Mišo Leković, Pripreme nemačkih štabova za ofanzivu na Kozaru u leto 1942. godine, Kozara u narodnooslobodilačkoj borbi i socijalističkoj revoluciji (1941-1945.), radovi sa naučnog skupa održanog na Kozari (Mrakovici) 27. i 28. oktobra 1977 godine, odgovorni urednik Joco Marjanović, Prijedor 1980, 223.

${ }^{12}$ Zbornik dokumenata i podataka o NOR-u, tom XII, knjiga 2, Dokumenti Nemačkog Rajha 1942., Beograd 1976, dok. br. 93.

${ }^{13}$ Isto, Prilog I. 
Savu. Od sredine srpnja i tijekom kolovoza 1942. Kraljevska mađarska dunavska flotila sudjelovala je u osiguranju prometa Dunavom od Vukovara do Novog Sada, a njezini ratni brodovi u istom su razdoblju pružali i potporu njemačkoj vojsci i postrojbama NDH tijekom borbi protiv partizanskih jedinica koje su djelovale u Srijemu, odnosno na Fruškoj gori. ${ }^{14}$

Zapovjedništvo II. domobranskog zbora u Brodu na Savi je u izvješću o stanju tijekom prve polovice srpnja 1942, u rubrici o odnosima sa "savezničkim vojskama“, navelo da su odnosi domobranstva s posadama mađarskih riječnih ratnih brodova bili „korektni“, a mađarskim mornarima koji su sudjelovali u operaciji protiv partizana na Kozari uručena su i hrvatska odlikovanja: „Odlikovanje dato zapovjedniku i posadi mađarske riječne flotile učinilo je na njih najbolji utisak. Suradnja flotile kod podhvata na Kozari bila je plodonosna. Topovnjače sa većim gazom upućene su na Dunav zbog sprečavanja prelaza partizana iz Fruške gore u Mađarsku [Bačku] ili iz ove u Frušku goru". ${ }^{15}$

Može se spomenuti da je mađarski monitor PM 1, koji je sudjelovao u blokadi partizana na Kozari, posjetio Sisak u 17. srpnju 1942. godine. Tom prilikom Mađari su kontaktirali s hrvatskim predstavnicima, što je proteklo u „srdačnom“ duhu. ${ }^{16}$

Kao što se vidi $u$ borbama protiv partizana postajala je potreba za riječnim ratnim jedinicama. Budući da Mornarica NDH tim jedinicama nije raspolagala, u operaciji na Kozari korištene su brodovi Kraljevske mađarske dunavske flotile. No, za NDH problem se nalazio u tome što njezini odnosi s Mađarskom nisu bili bez nesuglasica. Između te dvije države postojali su diplomatski odnosi, ali Zagreb nije priznavao mađarsku aneksiju Međimurja koja je provedena nakon sloma Kraljevine Jugoslavije. ${ }^{17}$ Isto tako s hrvatske strane postojale su sumnje, i u tom smislu bile su prisutne različite glasine da će Mađarska iskoristiti nestabilno stanje u NDH kako bi svojom vojskom zaposjela, a zatim i anektirala Slavoniju i Srijem. ${ }^{18}$ Uzevši u obzir navedeno vlasti NDH nisu mogle biti potpuno zadovoljne zbog prisutnosti mađarskih ratnih brodova na hrvatskim rijekama. To se vidi iz izvješća koje

${ }^{14}$ Isto, dok. br. 121, dok. br. 141.

${ }^{15}$ Zbornik dokumenata i podataka o NOR-u, tom V, knjiga 32, Borbe u Hrvatskoj 19411942. godine, Beograd 1964, dok. br. 134.

${ }^{16}$ Isto, dok. br. 135.

${ }^{17}$ Tomislav Jonjić, Hrvatska vanjska politika 1939.-1942., Zagreb 2000, 534-564.

${ }^{18}$ Tako se početkom 1942. u domobranskom izvješću navodi da predstavnici mađarskih pograničnih vlasti šire glasine da će mađarska vojska zaposjesti Slavoniju. Vidjeti: Građa za historiju Narodnooslobodilačkog pokreta u Slavoniji, Knjiga II, Slavonski Brod 1963, dok. br. 50. Početkom 1943. u jednom domobranskom izvješću navodi se da se šire glasine da će mađarska vojska zavesti red u istočnom dijelu NDH, odnosno da će Srijem biti pripojen Mađarskoj. Vidjeti: Građa za historiju NOP-a u Slavoniji, Knjiga IV (1. I - 31. III 1943), Slavonski Brod, 1965, dok. br. 46 . 
je Obalno zapovjedništvo Mornarice NDH u Zemunu početkom studenog 1942. uputilo Zapovjedništvu mornarice u Zagrebu. U njemu je spomenuto da se mađarska manjina u Srijemu prema hrvatskoj državi drži „rezervirano“, šireći promidžbu za priključene Srijema Mađarskoj. Prisutnost mađarske riječne flotile na Dunavu i Savi u znatnoj mjeri ide u prilog takvim težnjama mađarske manjine. Obalno zapovjedništvo u Zemunu zaključilo je da je zbog prethodno navedenog „vrlo potrebno“ da se žurno ustroje riječne jedinice Mornarice NDH. To bi na početku trebali biti naoružani izvidnički čamci, dok bi se do proljeća 1943. na hrvatskim rijekama svakako trebale pojaviti riječne topovnjače Mornarice NDH. No, zapravo je $u$ istom izvješću, u vezi s moralom i vojničkim duhom hrvatskih mornara, također navedeno: „Dobri su i popravljaju se kod momčadi, jer je ukrcavanjem dočastnika na motorne čamce, kao i topovnjače koje se dižu ovo osoblje opet privedeno svojoj iskonskoj službi, tj. zaposleno u svojoj struci“ ${ }^{19}{ }^{19}$

Pri ovome se očito mislilo na to da je Mornarica NDH u tom razdoblju u svoj sastav uvrstila spomenute riječne redarstvene čamce. Osim toga, Mornarica NDH angažirala je Tvornicu vagona, strojeva i mostova d. d. u Brodu na Savi da izvrši dizanje potopljenih riječnih ratnih brodova bivše Kraljevine Jugoslavije, kako bi oni mogli biti uvršteni u sastav Mornarice $\mathrm{NDH}^{20}$

Glavne jedinice Riječne ratne flotile Kraljevine Jugoslavije bila su četiri monitora („Drava“, „Morava“, „Sava“, „Vardar"). Ti monitori su do 1918. bili u sastavu austrougarske riječne mornarice. Tijekom napada sila Osovine na Jugoslaviju u travnju 1941. mađarski i njemački zrakoplovi napadali su i konačno na Dunavu potopili monitor „Drava“. Ostala tri monitora potopile su vlastite posade u noći 11/12. travnja. Monitori su potopljeni na ušću Save u Dunav, kraj Beograda. Posade su same potopile i druge riječne jedinice. Tako je komandni brod jugoslavenske riječne ratne flotile "Cer" potopljen kraj Županje. ${ }^{21}$ Podizanje nekih od ovih brodova za potrebe Mornarice NDH započelo je 1942. godine. Tako je podignut monitor „Morava“, koji je preimenovan u Riječna topovnjača „Bosna“, kao i monitor „Sava", koji je to ime zadržao i kao riječna topovnjača u sastavu Mornarice NDH. Nakon dizanja na površinu „Bosna“ i "Sava“ odvezeni su u Brod na Savi, da bi bili popravljeni i osposobljeni za upotrebu. ${ }^{22}$ Prema dokumenti-

${ }^{19}$ Hrvatski državni arhiv, Zagreb (HDA), Služba državne sigurnosti Republičkog sekretarijata za unutrašnje poslove Socijalističke Republike Hrvatske (SDS RSUP SRH), Zbirka mikrofilmova 86, svitak 2 (ZM/86/2), snimke 394-397, NDH, Obalno zapovjedničtvo Zemun, Taj. Broj: 1528/1942.

${ }^{20}$ Petar Mardešić, Pomorstvo, IV dio: riečno brodarstvo (Zagreb 1944), 157.

${ }^{21}$ Kažimir Pribilović, Ratna mornarica Kraljevine SHS i Kraljevine Jugoslavije (19181941), Disertacija, Split 1980, 576-577.

${ }^{22}$ Mardešić, Pomorstvo, IV dio: riečno brodarstvo, 157-163. 
ma iz siječnja 1943. vidljivo je da su se riječne topovnjače „Bosna“ i „Sava“ nalazile u Brodu na Savu i da su tada bile podređene Obalnom zapovjedništvu Mornarice NDH u tom gradu. ${ }^{23}$

Tijekom veljače i ožujka 1943. na površinu je podignut i bivši jugoslavenski riječni ratni brod "Cer“, koji je preimenovan u Riječni matični brod „Vrbas". ${ }^{24}$

\section{Zapovjedništvo riječne flotile Mornarice NDH u Brodu na Savi 1943-1944.}

Od 1942. godine Mornarica NDH na rijekama je imala obalna zapovjedništva u Brodu na Savi i Zemunu. Čini se da je taj ustroj promijenjen 1. rujna 1943., kada je u Brodu na Savi osnovano novo Zapovjedništvo riječne flotile Mornarice NDH. To novo zapovjedništvo bilo je smješteno na Riječnom matičnom brodu „Vrbas“. Izgleda da je osnivanjem spomenutog zapovjedništva ukinuto dotadašnje Obalno zapovjedništvo u Brodu na Savi. Također je i Obalno zapovjedništvo u Zemunu preimenovano u Riječno zapovjedništvo, a ono je preuzelo zapovjedništvo nad svim lučkim poglavarstvima na Dravi, Dunavu i Savi. ${ }^{25}$

Pod Zapovjedništvom riječne flotile Mornarice NDH bili su Riječni matični brod „Vrbas“, Riječna topovnjača „Bosna“, Riječna topovnjača „Sava“, a kasnije i Riječna barkasa „Bosut“. Također su pod njezinim zapovjedništvom bili i spomenuti riječni redarstveni čamci. ${ }^{26}$ Zapovjednik riječne flotile NDH bio je kapetan korvete (brodski bojnik) Luka Jurković, a pregledani izvori omogućuju da se opišu neka djelovanja njezinih jedinica tijekom 1943. i 1944. godine.

U međuvremenu su partizani uveliko otežavali plovidbu Savom. Obalno zapovjedništvo Mornarice NDH u Zemunu je početkom studenog 1942. zaključilo da se, unatoč poduzetih operacija za suzbijanje partizana u Srijemu, njihova djelatnost nastavlja i „zauzima maha“ upravo u posavskim srijemskim selima. Veće skupine partizana su stalno prisutne na području Srijemska Rača - Račinovci, Bosut - Klještevica i Domuskela. Tako su prilike na rijeci Savi „sasvim nesređene“, a promet na njoj „praktički obustavljen“. Savom prometuju samo mali remorkeri i drvarice koji prevoze naj-

${ }^{23}$ HDA, SDS RSUP SRH, ZM/86/2, snimka 584, Hrvatska mornarica, Riečna topovnjača „Bosna“, Taj. Broj: 47/1943., snimka 585, Hrvatska mornarica, Riečna topovnjača „Sava“, Taj. Broj: 34/1943.

${ }^{24}$ Mardešić, Pomorstvo, IV. dio: riečno brodarstvo, 163.-166.

25 J. Vasiljević, Mornarica NOVJ, 386. Do navedenih podataka došao sam i pregledom snimaka dokumenata raznih riječnih lučkih poglavarstava i riječnih zapovjedništava Mornarice NDH koji se nalaze na: HDA, SDS RSUP SRH, ZM/86/2.

${ }^{26}$ J. Vasiljević, Mornarica NOVJ, 386. 
nužniju robu, dok za svaku plovidbu većeg broda u donjem toku Save treba osigurati vojnu pratnju. Zato bi u Hrvatskoj Mitrovici trebalo zadržati Riječno-redarstveni odjel Mornarice NDH, iako je nedugo prije određeno da se on premjesti u Županju. ${ }^{27}$ Gotovo godinu dana kasnije, u rujnu 1943., kada su vlasti NDH razmatrale mogućnosti prijevoza živežnih namirnica koje su otkupljene od seljaka u Slavoniji i Srijemu, spomenuta je i mogućnost da se te namirnice prevoze riječnim putem. No, zaključeno je da se prijevoz teglenicama i šlepovima može organizirati na Dravi i Dunavu, ali to nije moguće provesti na rijeci Savi. ${ }^{28}$

Nesigurnost plovidbe Savom pokazala se i kada su redarstveni čamci „Ustaša“ i „Petrinjčica“ početkom studenog 1943. dobili zadatak da iz Broda isplove za Brčko. Zbog niskog vodostaja u Brčko se nije mogla uputiti Riječna topovnjača „Sava“. „Ustaša“ je teglio deregliju s hranom za domobransku posadu u Brčkom, a „Petrinjčica“ mu je trebala davati pratnju. $\mathrm{Na}$ „Petrinjčici“ se nalazilo i nekoliko domobranskih časnika i supruga domobranskih časnika koje su putovale u Brčko svojim muževima. U Županji se na deregliju ukrcalo i oko 30 domobrana koji su također putovali u Brčko. Zapovjednici „Ustaše" i „Petrinjčice“ imali su podatke da bi ih mogli napasti partizani, ali su ipak nastavili plovidbu prema Brčkom. U poslijepodnevnim satima 3. studenog 1943. partizani su u blizini Brčkog, s bosanske obale, napali oba redarstvena čamca. „Ustaša“ je projektilima iz protuoklopnih pušaka pogođen u spremnik goriva, te se zapalio i nasukao na slavonskoj obali. Posada „Ustaše" i domobrani s dereglije uspjeli su se iskrcati i doći do Brčkog. Partizani su pogodili i „Petrinjčicu“ i ranili nekoliko članova posade i drugih osoba koje su bile na tom čamcu, od kojih su neki kasnije podlegli ranama. „Petrinjčica“ je ipak uspjela doploviti do Brčkog. Kada je o svemu obaviještena domobranska i njemačka posada u Brčkom, ona je uputila snage da potisnu partizane s mjesta s kojeg su napali „Petrinjčicu“ i „Ustašu“. U međuvremenu je „Ustaša“ potpuno izgorio. Partizani su deregliju koju je „Ustaša" teglio preveli do bosanske obale, odnijeli su hranu koja se na njoj nalazila, a deregliju su zapalili. Zapovjedništvo riječne flotile je odredilo da Riječna topovnjača „Sava“, čim naraste vodostaj, otplovi u Brčko kako bi doteglila „Petrinjčicu“ nazad u Brod na Savi i kako bi također poduzela mjere na spašavanju „Ustaše“. ${ }^{29}$

${ }^{27}$ HDA, SDS RSUP SRH, ZM/86/2, snimke 394-397, NDH, Obalno zapovjedničtvo Zemun, Taj. Broj: 1528/1942.

${ }^{28}$ Građa za historiju NOP-a u Slavoniji, Knjiga VII (1. VIII - 30. IX 1943), Slavonski Brod 1970, dok. br. 115.

${ }^{29}$ HDA, Zbirka mikrofilmova gradiva iz inozemnih arhiva koje se odnosi na Hrvatsku, Vojni arhiv, Beograd, svitak D-2220, snimke 10-17, NDH, Ministarstvo oružanih snaga, Glavni stožer, Operativni odjel, Taj. Broj: 10853/1943.; Zbornik dokumenata i podataka o NOR-u, tom IV, knjiga 19, Borbe u Bosni i Hercegovini 1943 god. - novembar, Beograd 1959, dok. br. 173. 
Riječna topovnjača „Sava“ je 15. prosinca 1943. plovila iz Broda na Savi prema Bosanskoj Gradiški. Topovnjača je tijekom tog krstarenja otvarala paljbu na partizane koji su se nalazili na bosanskoj obali Save, ali su i partizani iz protuoklopne puške pogodili topovnjaču i ranili nekoliko članova njezine posade. ${ }^{30}$

Početkom 1944. u NDH se, s izobrazbe u Francuskoj i Njemačkom Reichu, vratila 13. SS gorska divizija „Handžar“, koja je znatnim dijelom bila popunjena bosansko-hercegovačkim muslimanima. Divizija se po dolasku prvo razmjestila na području istočne Slavonije i Srijema. Kasnije se prebacila preko Save i nastavila djelovati u Bosni. No, prije odlasku u Bosnu postrojbe te divizije dobile su zadatak da tijekom ožujka 1944. očiste Bosutske šume od partizana. Na tom području nalazilo se partizansko središte za održavanje veze Slavonije i Srijema s Bosnom. Kako bi partizani u Bosutskim šumama bili uništeni, bilo je važno na tom području blokirati rijeku Savu, da se partizani ne bi mogli povući u Bosnu. Za ovaj zadatak Mornarica NDH je Nijemcima na raspolaganje stavila Riječnu topovnjaču „Bosna“, koja je trebala osiguravati Savu između Jamena i Srijemske Rače. Na „Bosni“ se nalazio i njemački časnik za vezu iz 13. SS divizije. Dana 11. ožujka 1944. „Bosna“ se sukobila s partizanima kod Domuskele, i tada je od partizanske paljbe poginuo jedan pripadnik njezine posade. No, zapovjednik "Bosne“ nije bio spreman izvršiti sve zapovjedi njemačkog časnika za vezu, koji se kod Srijemske Rače iskrcao s topovnjače, kako bi uspostavio vezu s postrojbama svoje divizije. Kada se taj časnik pokušao vratiti na „Bosnu“, shvatio je da je ona napustila to područje, očito zato jer je njezin zapovjednik ocijenio da bi zadržavanjem na tom dijelu Save mogao svoju topovnjaču dovesti u opasnost od partizanskog napada. Iako su Nijemci u čišćenju Bosutskih šuma partizanima nanijeli gubitke, oni su ipak uspjeli izbjeći potpuno uništenje, a dio partizana se preko Save povukao u Bosnu. ${ }^{31}$

Krajem lipnja 1944. partizani su napali Derventu. Zapovjedništvo II. zbornog područja u Brodu na Savi poduzelo je mjere da se posadi u Derventi pruži pomoć, pa je, među ostalim, zapovjedilo Riječnoj topovnjači „Sava“ da iz Broda na Savi isplovi uzvodno prema Dubočcu, kako bi spriječila da partizani iz Slavonije eventualno prijeđu Savu i sudjeluju u napadu na Derventu. Na kraju je Derventa ipak pala u ruke partizana. ${ }^{32}$ Nedugo kasnije, 16. srpnja, Riječna topovnjača „Bosna“ je kraj Bosanskog Novigra-

${ }^{30}$ Građa za historiju NOP-a u Slavoniji, Knjiga IX (15. XI - 31. XII 1943), Slavonski Brod 1981, dok. br. 145.; Zbornik dokumenata i podataka o NOR-u, tom IV, knjiga 20, Borbe u Bosni i Hercegovini 1943 god. - decembar, Beograd 1960, dok. br. 228.

${ }^{31}$ George Lepre, Himmler's Bosnian Division, The Waffen-SS Handschar Division 19431945, Atglen, PA, 1997, 143-151.

${ }^{32}$ Zbornik dokumenata i podataka o NOR-u, tom IV, knjiga 27, Borbe u Bosni i Hercegovini 1944. godine - jul, Beograd 1967, dok. br. 162. 
da, uzvodno od Bosanskog Šamca, naišla na minu i potonula. Pri tome su poginuli zapovjednik i još jedan časnik, kao i 12 mornara. ${ }^{33}$ Potonuće „Bosne“ zapravo je bila posljedica činjenice da su u tom razdoblju angloamerički zrakoplovi u rijeku Savu počeli bacati mine što je, uz djelovanje partizana, bio dodatan razlog za obustavu plovidbe tom rijekom. Tako Lučko poglavarstvo Hrvatska Mitrovica u svom izvješću od 20. srpnja 1944. navodi: „Na rieci Savi vrši se promet samo između Bosuta i Hrvatske Mitrovice i to prevoz drva iz šume Klještevica u Mitrovicu za potrebe domobranstva i samog grada. Promet na ostalom potezu obustavljen uslied ugroženosti od odmetnika, a u zadnje vrieme i radi polaganja mina koje vrše neprijateljski zrakoplovi“. 34

Njemački Mornarički stožer za vezu Hrvatska je u izvješću od 1. kolovoza 1944. spomenuo gubitak Riječne topovnjače „Bosna“, dodajući da bi Mornarica NDH na Dunavu i Savi mogla odigrati veću ulogu u čišćenju mina i suzbijanju partizana, kada bi joj što žurnije bilo isporučeno sedam ophodnih motornih čamaca koji se grade u Njemačkom Reichu. Zato su poduzete mjere da se isporuka tih čamaca ubrza. Isto tako, spomenuto je $u$ tom izvješću, i u Zagrebu je započela gradnja 12 motornih čamaca za potrebe Mornarice NDH na rijekama. ${ }^{35}$ Zapravo je Mornarica NDH još početkom lipnja 1944. s Tvornicom uskotračnog željezničkog materijala, čiji je vlasnik bio dr. M. G. Rašića, sklopila ugovor o izgradnji 12 oklopljenih motornih čamaca, a isporučeno ih je sedam. ${ }^{36}$

No, ubrzo će nepovoljan razvoj stanja za sile Osovine dovesti do daljnjeg slabljenja, štoviše, moglo bi se reći i do zamiranja djelovanja Mornarice NDH na rijekama. Krajem ljeta 1944. sovjetska Crvena armija je kroz jugoistočnu Europu napredovala prema granicama NDH, a širile su se i glasine o iskrcavanju zapadnih saveznika na hrvatskom dijelu Jadrana. U takvim okolnostima maršal Josip Broz Tito je 30. kolovoza 1944. pozvao hrvatske domobrane da do 15. rujna pristupe partizanima, dok je domobranima koji to ne učine zaprijetio izvođenjem pred sud koji će ih, kao izdajnike, najstrože kazniti. U stanju kakvo je tada vladalo Titov poziv imao je odjeka $\mathrm{u}$ redovima domobranstva, pa je tijekom rujna došlo do osipanja i rasula $\mathrm{u}$ brojnim njegovim postrojbama. ${ }^{37}$ Tako je i iz Broda na Savi od 9. do 11. rujna 1944. partizanima prebjeglo dosta domobrana i njihovih časnika. U par-

33 J. Vasiljević, Mornarica NOVJ, 386.; Zbornik dokumenata i podataka o NOR-u, tom XII, knjiga 4, dok. br. 102.

${ }^{34}$ HDA, SDS RSUP SRH, svitak 2, snimke 566-567, Lučko poglavarstvo Hrvatska Mitrovica, Taj. Broj: 72/1944.

${ }^{35}$ Zbornik dokumenata i podataka o NOR-u, tom XII, knjiga 4, dok. br. 102.

${ }^{36}$ J. Vasiljević, Mornarica NOVJ, 386.

${ }^{37}$ Nikica Barić, Ustroj kopnene vojske domobranstva Nezavisne Države Hrvatske, 1941.1945., Zagreb 2003, 492-504. 
tizane su otišli i „gotovo svi“ pripadnici Mornarice NDH, koji su prije bijega potopili Riječnu topovnjaču "Sava“. ${ }^{38}$ Prema drugim podacima mornari Riječne flotile u Brodu na Savi su 11. rujna 1944. potopili Riječnu topovnjaču "Sava“, ali i dio redarstvenih čamaca, a također su onesposobili i Riječni matični brod „Vrbas“, a zatim su posade tih brodova prebjegle partizanima. $^{39}$

U listopadu 1944. Crvena armija i partizani zauzeli su Beograd, a ubrzo su partizani ovladali i znatnim dijelom Srijema. Tako je u njihove ruke pao i Zemun, sjedište Riječnog zapovjedništva Mornarice NDH. Nedugo prije ovih događaja, 7. listopada 1944., dio hrvatskih mornara u Zemunu također je prebjegao partizanima. ${ }^{40}$

Za razdoblje nakon rujna/listopada 1944. ne raspolažem nikakvim podacima o djelovanju Mornarice NDH na rijekama. Nakon što su partizani pri samom kraju rata, u travnju 1945., zauzeli Brod na Savi, tamo su zatekli neke redarstvene čamce Mornarice NDH, koje su odmah iskoristili za svoje potrebe. $^{41}$

\section{Naoružana plovila drugih postrojbi NDH i njemačke vojske na rijekama}

I druge postrojbe NDH, kao i njemačka vojska koja je djelovala na njezinom teritoriju imali su, odnosno željele su imati vlastita naoružana plovila.

Sredinom 1943. partizanski obavještajci primijetili su da „neprijatelj“ iz „uporišta Jasenovac“ ponekad „znade krstariti uz vodu i niz vodu sa motornim naoružanim čamcima". ${ }^{42}$ Iz ovoga se može pretpostaviti da je Ustaški obrambeni zdrug, koji je osiguravao koncentracijski logor Jasenovac i okolno područje, imao na raspolaganju motorne naoružane čamce. ${ }^{43}$ Uostalom, kada je početkom 1942. razmatran „nacrt obrane područja oko Jasenovca" odlučeno je ustrojiti privremeni domobransko-ustaški Gradiški zdrug čiji je važan operativni cilj među ostalim bio i spriječiti svaki dodir

${ }^{38}$ Zbornik dokumenata i podataka o NOR-u, tom I, knjiga 17, Borbe u Vojvodini 19411944 god., Dokumenti okupatorskih i kvislinških jedinica, Beograd 1958, dok. br. 165.

${ }^{39}$ Slavica Hrečkovski, Slavonski Brod u NOB i socijalističkoj revoluciji 1941-1945., Slavonski Brod 1982, 236.

${ }^{40}$ HDA, Zbirka zapisa upravnih i vojnik vlasti NDH i Narodnooslobodilačkog pokreta (dalje: ZZ NDH), I-10/194, B-II-,,D“. Šofer dopukovnika Drachslera odvezao krugovalnu postaju mornarice, I-42/79-80, Bieg pripadnika zrakoplovne i mornaričke krugovalne postaje u Zemunu sa krugovalnim uređajima. - „Kuzmić“ dana 11. X. 1944. - dostavlja sliedeće.

${ }^{41}$ J. Vasiljević, Mornarica NOVJ, 401.

${ }^{42}$ Građa za historiju NOP-a u Slavoniji, Knjiga VI (1. VI - 30. VII 1943), Slavonski Brod 1968, dok. br. 100.

${ }^{43}$ Davor Marijan, Ustaške vojne postrojbe 1941.-1945., magistarski rad, Zagreb 2004, 43. 
„komunista-četnika“ južno i sjeverno od Save. ${ }^{44}$ Upravo će iz Gradiškog zdruga nešto kasnije biti ustrojen Ustaški obrambeni zdrug.

U jesen 1943. njemačka Dunavska ratna flotila imala je sjedište $u$ Beogradu, a njezine jedinice djelovale su i na rijeci Savi. ${ }^{45}$ No, njemačka kopnena vojska željela je na Savi imati i vlastite plovne jedinice. U ljeto 1943. u NDH je raspoređen njemački LXIX. pričuvni zbor, čije se zapovjedništvo nalazilo u Vukovaru, kasnije Vinkovcima, a postrojbe pod njegovim zapovjedništvom djelovale su na području sjeverno od Save. ${ }^{46}$ Zapovjedništvo tog zbora je tijekom druge polovice studenog 1943. zaključilo da su brodovi njemačke Dunavske flotile, zbog dubokog gaza i nedovoljne pokretljivosti, neprikladni za korištenje na Savi. Zato je zatraženo da se za LXIX. pričuvni zbor osigura šest brzih motornih čamaca s gazom do 60 centimetara. Ti čamci, s posadom od osam ljudi, bili bi oklopljeni kako bi štitili posadu od paljbe iz pješačkog oružja i lakih protuoklopnih topova. Trebali su biti naoružani jednim lakim topom i s dvije strojnice. Zapovjedništvo LXIX. pričuvnog zbora obrazložilo je da nije u stanju spriječiti partizane da prelaze Savu. Zapravo, duž Save, između Jasenovca i Broda, ne postoji niti jedna posada njemačke vojske ili postrojbi NDH. Takve posade također ne postoje ni između Broda i Brčkog, osim u Županji, a niti između Brčkog i Hrvatske Mitrovice. Zbog nedostatka snage takve se posade za osiguranje Save niti ne mogu uspostaviti Kada bi se dobili zatraženi oklopljeni naoružani motorni čamci, onda bi se lakše nadzirala Sava i moglo bi se spriječiti da veće skupine partizana prelaze preko te rijeke. Ti čamci vršili bi stalne ophodnje i mogli bi na vrijeme primijetiti da partizani namjeravaju prijeći Savu, nakon čega bi se mogle uputiti postrojbe koje bi takve prelaske onemogućile. Zapovjedništvo LXIX. pričuvnog zbora također je tražilo da posade zatraženih šest čamaca budu pripadnici kopnene vojske, a ne njemačke Ratne mornarice. Posade s njemačkim mornarima bi bile prihvatljive isključivo ako će one biti podređene Zapovjedništvu LXIX. pričuvnog zbora. ${ }^{47} \mathrm{No}$, njemačka Ratna mornarica odgovorila je da ne raspolaže brzim motornim čamcima kakvi su zatraženi za djelovanje na Savi. ${ }^{48}$ Po primitku ovog odgovora Zapovjedništvo LXIX. pričuvnog zbora tražilo je da se razmotri mogućnost da se zatraženih šest motornih čamaca osigura među takvim

${ }^{44}$ HDA, ZZ NDH, I-63/198-199, Ustaška nadzorna služba, Zapovjedničtvo, Broj U. Z. Prs. 400/1942.

${ }^{45}$ National Archives and Record Administration, Washington DC (NARA), T-313, Roll 192, Frame 7452702, Panzer A. O.K. 2, Ia, Abtlg. Nr. 376/43 geheim.

${ }^{46}$ Gorčin Raičević, Pregled jedinica i štabova nemačke kopnene vojske u Jugoslaviji 1941-1945, Vojnoistorijski glasnik, br. 2, Beograd 1967, 341.

${ }^{47}$ NARA, T-313, Roll 192, Frame 7452673, Panzer A. O.K. 2, Ia, Abtlg. Nr. 1951/43 geheim.

${ }^{48}$ NARA, T-313, Roll 192, Frame 7452662, Pz. A. O.K. 2, Ia, Nr. 2406/43 geheim. 
plovilima koja se trenutno koriste na njemačkim rijekama u civilne svrhe, nakon čega bi na njih trebalo ugraditi zaštitni oklop i zatim ih upotrijebiti na Savi. ${ }^{49}$ Nažalost, dokumenti koje sam pregledao ne daju odgovor kako je ovo pitanje na kraju riješeno i da li je Zapovjedništvo LXIX. pričuvnog zbora dobilo zatražene oklopljene i naoružanje čamce potrebne za nadziranje rijeke Save.

\section{Sudjelovanje Mornarice NDH u radu njemačkog Nadzorništva za čišćenje mina na Dunavu}

U sklopu zračne ofenzive koju su zapadni saveznici u kasnijem razdoblju rata vodili protiv sila Osovine, njihovi zrakoplovi su tijekom 1944. počeli bacati mine u Dunav i Savu, a također su vršeni zračni napadi na promet koji se odvijao tim rijekama. Promet Dunavom bio je za Nijemce važan jer se strateški važna nafta iz rumunjskih izvora tom rijekom prevozila u Njemački Reich. Od travnja do listopada 1944. od mina koje su u Dunav bacili angloamerički zrakoplovi, kao i u zračnim napadima, potopljen je veći broj brodova, tankera i teglenica. ${ }^{50}$

Riječno zapovjedništvo u Zemunu je 26. lipnja 1944. Zapovjedništvu Mornarice NDH uputilo dopis u vezi sa zahtjevom njemačkog Nadzorništva za čišćenje mina na Dunavu. To njemačko tijelo zatražilo je da se na rijeci Savi ubrzo uspostavi „flotila tražioca mina“. Nju bi činili motorni čamci Mornarice NDH ili rekvirirana privatna plovila. Plovila ove flotile bila bi pod zapovjedništvom Mornarice NDH i na njima bi se vijala hrvatska zastava. Njemačko nadzorništvo Savu smatra „izrazito hrvatskom“ rijekom i ne namjerava na njoj, za otkrivanje mina, rasporediti osoblje ili plovila njemačke Dunavske flotile. Kako je zaključilo Riječno zapovjedništvo u Zemunu, ako bi došlo do osnivanja hrvatske „flotile tražioca mina“, onda bi za nju trebalo osigurati potrebno stručno osoblje, a ta bi flotila na Savi djelovala na dva poteza - od Broda na Savi do Srijemske Rače i od Srijemske Rače do ušća Save u Dunav. No, njemačko Nadzorništvo za čišćenje mina na Dunavu od Mornarice NDH također je zahtijevalo da ona pruži pomoć i $\mathrm{u}$ čišćenju mina na rijeci Dunav. U vezi s ovim Riječno zapovjedništvo $u$ Zemunu zaključilo je da bi se za čišćenje mina na Dunavu trebalo upotrijebiti dva broda „Hrvatskog riječnog brodarstva“ („Hribrod“), primjerice "Drava“ i „Nehaj“. Za te brodove trebalo bi odrediti osoblje Mornarice NDH

${ }^{49}$ NARA, T-313, Roll 192, Frame 7452661, Panzer A. O.K. 2, Ia, Abtlg. Nr. 2628/43 geheim.

${ }^{50}$ J. Vasiljević, Mornarica NOVJ, 392-393.; Mark Axworthy, Cornel Scafeş, Cristian Craciunoiu, Third Axis, Fourth Ally, Romanian Armed Forces in the European War, 1941-1945, London 1995, 314. 
i „Hribroda“, dok bi dio stručnog osoblja na tim brodovima trebali popuniti Nijemci. Riječno zapovjedništvo u Zemunu iznijelo je mišljenje da Zapovjedništvo Mornarice NDH daje naglasak na popunu plovnih jedinica NDH na Jadranu, ali bi ono također trebalo imati u vidu i osiguranje ljudstva za riječnu službu. Na Dunavu je stanje izuzetno teško jer angloamerički zrakoplovi u tu rijeku bacaju mine koje nanose znatne gubitke riječnom prometu, koji je izuzetno važan za ratne napore sila Osovine. Zato treba računati, zaključilo je Riječno zapovjedništvo u Zemunu, da će njemačka strana ustrajati na tome da se Mornarica NDH uključi u čišćenje mine na Dunavu. ${ }^{51}$

Ubrzo će se pokazati da je njemačka strana ustrajna u svom zahtjevu da iskoristi hrvatske mornare i plovila za čišćenje mina na Dunavu. Tako je njemački Mornarički stožer za vezu Hrvatska u izvješću od 1. kolovoza 1944. naveo da je nedugo prije u Zemun stiglo nešto više od 100 pripadnika Mornarice NDH koji su uglavnom završili izobrazbu za čišćenje mina. Ti mornari trebali su biti razmješteni na plovnim jedinicama koje će raditi na razminiranju Dunava. Pri tome se trebalo paziti da ne rade zajedno sa Srbijancima, kako bi se izbjegla eventualna hrvatsko-srpska neslaganja. U međuvremenu su Nijemci za potrebe čišćenja mina na Dunavu rekvirirali hrvatske riječne putničke brodove „Petar Zrinski“ i „Zagreb“, koji su zatim prilagođeni za čišćenje mina. Ministarstvo obrta, veleobrta i trgovine NDH je zbog njemačke rekvizicije tih brodova njemačkim diplomatskim i vojnim predstavnicima u Zagrebu uložilo prosvjed, no Nijemci očito nisu imali namjere odustati da se ti brodovi što žurnije upotrijebe za čišćenje mina na Dunavu. Pri tome su njihovu posadu trebali činiti Hrvati i njemačko specijalističko osoblje, a brodovi su razminiranje Dunava trebali izvoditi pod hrvatskom zastavom. U istom je izvješću njemačkog Mornaričkog stožera za vezu Hrvatska također navedeno da Mornarica NDH namjerava sedam malih teglenica preurediti za čišćenje mina. Osim toga Zapovjedništvo Mornarice NDH je Riječnom zapovjedništvu u Zemunu i Zapovjedništvu riječne flotile u Brodu na Savi naredilo da se, u mjeri u kojoj to mogu, svojim plovnim jedinicama u potpunosti stave na raspolaganje njemačkom Nadzorništvu za čišćenje mina na Dunavu. ${ }^{52}$

Riječno zapovjedništvo u Zemunu je 1. kolovoza 1944. izvijestilo Zapovjedništvo Mornarice NDH da je odredilo osoblje za popunu posade broda „Zagreb“, koji je, kao pomoćni minolovac, trebao otploviti na Dunav na zadatak čišćenja mina. ${ }^{53}$ Riječno zapovjedništvo u Zemunu je 8. kolovo-

${ }^{51}$ HDA, SDS RSUP SRH, ZM/86/2, snimke 443-445, Riečno zapovjedničtvo u Zemunu, Taj. Broj: 744/1944.

${ }^{52}$ Zbornik dokumenata i podataka o NOR-u, tom XII, knjiga 4, dok. br. 102.

${ }^{53}$ HDA, SDS RSUP SRH, ZM/86/2, snimka 565, Riečno zapovjedničtvo u Zemunu, Taj. Broj: 894/1944. 
za obavijestilo zapovjednika pomoćnog minolovca „Zagreb“ da će njegov brod otploviti iz Zemuna za Pančevo, gdje će se javiti zapovjedniku njemačke minolovačke skupine za srednji Dunav. Zatim će „Zagreb“ ploviti zajedno s jednim njemačkim minolovcem, djelujući po nalozima njemačkog zapovjednika. Svrha ovoga bit će uvježbavanje posade „Zagreba“ za čišćenje mina, sve dok ne bude završeno opremanje pomoćnog minolovca „Petar Zrinski“. Nakon toga ova dva hrvatska pomoćna minolovca činit će posebnu skupinu za čišćenje mina. Riječno zapovjedništvo u Zemunu je zapovjedniku „Zagreba“ pred predstojeći zadatak dalo i cijeli niz uputa. Primjerice posada „Zagreba“ trebala je kod svakodnevnih vježbi posebnu pažnju obratiti izobrazbi posade protuzrakoplovnog topa i vježbanju gašenja požara na brodu. Isto tako zapovjednik "Zagreba" trebao je zabraniti svojoj posadi da pojedinačno izlaze u Pančevo ili po drugim „banatskim ili srbskim naseljima", ali su skupine mornara u pratnji dočasnike mogle u stroju otići na kino predstave ili druge priredbe. Posadu „Zagreba“ trebalo je uputiti na "dostojno i čvrsto" držanje u susretu sa srpskim stanovništvom, ali je s druge strane trebalo izbjegavati bilo kakav postupak koji bi izazivao ili vrijeđao srpsko stanovništvo. U slučaju da dođe do incidenata sa srpskim stanovništvom, zapovjednik „Zagreba“ bio je dužan da se odmah obrati nadležnom njemačkom zapovjedništvu s molbom da mu pruži potporu. ${ }^{54}$

Prema podacima koje sam pronašao na internetu, pomoćni minolovac „Zagreb“ je 7. rujna 1944. u blizini Zemuna naišao na minu i potonuo. Pomoćni minolovac „Petar Zrinski“ je 23. listopada 1944. u blizini Vukovara također naišao na minu i potonuo. ${ }^{55}$ Drugi podaci govore o tome da je hrvatski dio posade "Zagreba" početkom rujna 1944. razoružao Nijemce koji su bili raspoređeni na tom brodu, nakon čega su prebjegli partizanima na Fruškoj gori. ${ }^{56}$

\section{Završna razmatranja}

Pokušao sam u osnovnim crtama prikazati djelovanje Ratne mornarice NDH na rijekama. Za obradu ove teme na raspolaganju sam imao oskudne izvore, iako pretpostavljam da bi se daljnjim istraživanjem moglo doći do dodatnih podataka o ovoj temi. U Hrvatskom državnom arhivu u Zagrebu postoji veća količina mikrofilmova sa snimkama vojnih i drugih dokumenata NDH čiji se izvornici nalaze u Vojnom arhivu u Beogradu (bivši Arhiv Vojnoistorijskog instituta Jugoslavenske narodne armije). U beo-

${ }^{54}$ HDA, SDS RSUP SRH, ZM/86/2, snimke 563-564, Riečno zapovjedničtvo u Zemunu, Taj. Broj: 921/1944.

${ }^{55} \mathrm{http}$ ://www.forum-marinearchiv. de/smf/index. php? topic=4547.0, pristup ostvaren 17. kolovoza 1944.

${ }^{56}$ J. Vasiljević, Mornarica NOVJ, 392. 
gradskom Vojnom arhivu se, među ostalim, nalazi i arhivski fond Zapovjedništva Mornarice NDH (16 kutija dokumenata) i fond Obalnog zapovjedništva Mornarice NDH u Zemunu (56 dokumenata). ${ }^{57}$ No, dokumenti tih fondova, prema mom uvidu, nažalost nisu snimljeni na mikrofilmove koji se čuvaju u Hrvatskom državnom arhivu.

Mornarica NDH poduzimala je napore da uspostavi svoju riječnu flotilu i ona je znatnim dijelom bila raspoređena na Savi, s glavnim uporištem u Brodu na Savi. No, isto je tako vidljivo da Mornarica NDH nije bila u stanju osigurati siguran promet Savom jer su i na njezinoj slavonskoj i srijemskoj obali, kao i na njezinoj bosanskoj obali tijekom većeg dijela rata neprestano djelovale partizanske jedinice. Tako su partizani već od 1942. i 1943. znatnim dijelom onemogućili redoviti promet tom rijekom za civilne i gospodarske potrebe. Na temelju pregledanih izvora čini se da je Riječna ratna flotila NDH na Savi uglavnom bila zadužena da blokira prelazak partizana preko Save, ali taj zadatak očito nije mogla uspješno provesti. Može se reći da je, zbog gubitaka u plovilima (potonuće Riječne topovnjače „Bosna"), rasula u domobranstvu u rujnu 1944., koje je zahvatilo i hrvatske mornaričke postrojbe u Brodu na Savi, kao i pada Zemuna u ruke partizana, Mornarica NDH na Savi i drugim rijekama uglavnom prestala djelovati i znatno prije konačnog sloma NDH koji je uslijedio u svibnju 1945. godine.

${ }^{57}$ Arhivski fondovi $i$ zbirke $u$ arhivima $i$ arhivskim odeljenjima u SFRJ, Savezni arhivi, Beograd 1980, 159. 
Nikica Barić

\section{ACTIVITIES AND ORGANIZATION OF THE NAVY OF INDEPENDENT STATE OF CROATIA NAVY ON RIVERS}

\section{Summary}

According to the Rome agreements signed on May 18, 1941 by Benito Mussolini and the head of Independent State of Croatia (ISC) Ante Pavelić, Croatian side had to cede a large part of eastern Adriatic coast to Kingdom of Italy. Rome agreements also stipulated that ISC does not have right to develop navy at the parts of Adriatic coast that remained within the Croatian borders. After German attack on Soviet Union Croatian volunteers joined German and Italian troops fighting on the Eastern front. Croatian naval legion was also formed and it joined the German navy on the Black sea. After the capitulation of Italy in September 1943 Croatian authorities declared Rome agreements null and void and most of the areas annexed by Italians in 1941 were returned to Croatian rule. This opened the opportunity for the development of ISC Navy at the Adriatic. Unlike Italians before them, Germans were ready to help ISC to establish its naval forces. But because of the difficult situation during the later part of the war ISC Navy at the Adriatic was very limited in its operations. In late 1944 some ISC naval personnel defected to the Tito's partisans and after that Germans lost confidence in ISC Navy. From 1941 ISC Navy had port authorities and various commands on Croatian rivers (Danube, Drava and Sava). Its main bases were in Brod na Savi and Zemun. ISC Navy at rivers possessed several patrol boats. During Axis attack on Kingdom of Yugoslavia in April 1941 most of its river boats were scuttled by their crews. During 1942 and 1943 some of these boats were salvaged, among them two monitors („Bosna“ and „Sava"), and taken into service of the ISC Navy. Because of the activities of partisan forces operating in Slavonia, Syrmia and Bosnia regular traffic along river Sava was disrupted from 1942 and ISC Navy was not able to control the situation at that river. During 1944 Allied airplanes began laying mines in Sava and one of it hit and sank monitor „Bosna“. In late summer of 1944 Soviet Red army was approaching Croatian border and Marshal Tito issued a call to soldiers of Croatian Home Guards to join the partisans until September 15 or face consequences as "traitors". Many Home 
Guardsmen deserted their units and joined the partisans. ISC naval personnel in Brod na Savi scuttled monitor "Sava" and also deserted to partisans. In October 1944 Soviet and partisan forces captured Belgrade and eastern Syrmia, including Zemun. Because of such developments of events ISC Navy at rivers largely ceased to exist already in autumn of 1944, although the war lasted for several more months. 